\title{
Innovation and development of English education in colleges and universities in the new period
}

\author{
Yan Chen \\ Enshi Vocational and Technical College, Enshi, Hubei, 445000, China
}

\begin{abstract}
As an international language, English has an important influence on the future development of students. This paper mainly introduces the problems existing in English education in colleges and universities in China in the new period and the strategies for innovating English teaching in colleges and universities for reference.

Keywords: New period; College English Education; Innovation and Development Strategies

DOI: $10.36012 /$ fhe.v1i1.890
\end{abstract}

\section{Introduction}

I $\mathrm{n}$ the new period, our country has become more and more open to the outside world, and the university students are the future of the motherland. In order to make it better adapt to the trend of globalization, we need to strengthen the English education of contemporary college students. However, at the present stage, there are some shortcomings in the English education in China, which, to some extent, hinder the development of English education in colleges and universities. Therefore, it is necessary to adopt some innovative measures to improve the English education.

\section{2. the problems existing in English education in colleges and universities in the new period.}

2.1 The organization of English curriculum management in colleges and universities need to be further improved

As an important course in the teaching of higher learning, college English plays an important role in improving the management mode and management efficiency of English teaching in colleges and universities. In addition, the management level of the college English course management organization can directly reflect the students' English and English teachers' professional quality. Through the investigation and research, most of the institutions of English course management in most colleges and universities in China are similar, and the organization is mainly divided and clearly defined for the teaching and research group, and the teaching and research for the professional English characteristic setting is lacking. There is a lack of individualized training in students' English learning, so it is necessary to further improve the curriculum management organization.

\subsection{Curriculum objectives need to be further im-} proved

In the new period, the goal of English teaching in colleges and universities should be "to train a large number of high-level talents who not only know their specialties but also have certain English application ability, strengthen the cultivation of comprehensive English application ability, and improve the quality of English teaching in colleges and universities". This requires that English teaching in colleges and universities should set up detailed and scientific curriculum objectives and establish a goal system or target system with "hierarchy" ${ }^{[2]}$. However, at this stage, there are still some problems in the setting of English curriculum objectives in many colleges and universities in our country. The objectives are too general. Many schools have only set up the general objectives of the curriculum, and have not subdivided the overall goals into specific sub-goals, resulting in college students' English Language level can not be effectively improved, 
college English teaching can not meet the needs of today's social development.

\subsection{Teaching model to be innovated}

With the rapid development of information technology and network technology, computer-aided teaching has been valued and ap plied. At present, however, the teaching mode of college English teaching in our country is relatively old, the teaching lack of innovation and times. The multimedia some teachers use is too simple, not fully excavating the value of multimedia, but simply moving the knowledge in the textbooks to the large screen, the teaching mode is still relatively textual, lack of certain flexibility, which makes the communication time and opportunities between college students and teacher are still less. In addition, this teaching mode is very easy for students to develop passive learning. In the habit of passive thinking, students often study in order to complete the tasks assigned by the teacher, and lack of initiative and enthusiasm in learning, which affects the learning efficiency.

\section{4 the quality of teachers needs to be improved}

In the Curriculum requirements, it is clearly pointed out that contemporary colleges and universities should build teachers with reasonable age, academic qualifications and professional title structure, and at the same time, schools should provide teachers with corresponding opportunities for further study in order to ensure that teachers' teaching level can be continuously improved ${ }^{[3]}$. However, the teachers in some colleges and universities are very weak, although the proportion of teachers with doctorates has increased compared with the previous years, but on the whole, the professional level of English teachers still needs to be further improved. In addition, because the enrollment scale of many colleges and universities is expanding, but the number of teachers is limited, the teaching task of teachers is relatively heavy, which is also to a large extent.

\section{In the new period, the paper aims at the problems existing in college English teaching.}

\section{1 optimize teaching objectives and establish a multi-level curriculum goal system}

Contemporary colleges and universities should further optimize the teaching objectives of English courses, divide the overall objectives in detail, and establish a multi-level curriculum goal system. Specifically, in addition to improving students' comprehensive English application ability as the teaching goal, we should also try to improve students' humanistic literacy and comprehensive cultural literacy ${ }^{[4]}$. In the process of cultivating students' humanistic literacy, it is helpful to broaden students' horizons and make students understand the world more, so that students can walk to the international stage more smoothly after graduation. Schools can set up English language courses, oral English communication courses, etc., or offer corresponding elective courses, such as English Courses such as aesthetic education and appreciation of works.

\section{2 optimizing the content of English teaching ma- terials}

The reform and innovation of the content of English teaching materials is a long-term and complex process. In the course of the innovation of English education, it is difficult to meet the development of the educational cause. In order to change the situation, the contents of the English teaching materials need to be optimized by the schools and the teachers. In general, we can start with the following two aspects: first, to increase the proportion of the English listening and speaking module in the teaching material, to strengthen the training of the students' ability to use the language and the innovation ability, and to improve the comprehensive quality of the college students; and secondly, to improve the English teaching materials, So that it is more in line with the needs of the college students and the social development. When developing English teaching materials, teachers should combine with the English education program In this way, the role of English teaching materials can be brought into full play in order to cultivate outstanding English talents.

\subsection{Change the teachers' educational concept and} strengthen students'cognition of English knowledge. Under the background of the new period, the educational concept of college English teachers should be changed with the development of the times ${ }^{[5}$. As a non-native language, the students have a certain difficulty in learning, which is easy to produce negative slack. In this regard, teachers should strengthen the popularization of English culture, make college students better understand the cultural background of English and deepen the sense of English language. Although the quality education has been carried out in China, the teaching objectives formulated by many colleges and universities are still focused on improving students' performance. In order to improve the students' ability 
to study, it is difficult to improve the students' comprehensive quality. Therefore, the teachers should train the students in many ways, and improve the students' comprehensive ability and carry out the quality-oriented education.

\subsection{Make full use of modern information technology and improve the times of teaching}

3.4.1 give full play to the function of multimedia and improve students' interest in learning

The application of multimedia in colleges and universities is too single, and the advantage of multimedia technology should be fully brought into play ${ }^{[6]}$. Compared with the traditional teaching method, the application of the multi-media teaching can fully mobilize the students' visual and auditory system, attract the students' attention, and stimulate the students' interest in learning, so that the atmosphere of the classroom is active and the efficiency of the classroom teaching is improved. For example, if a person is involved in the course, the teacher can expand the life background and experience related to the person through the multimedia, so that the students have a better understanding of the characters so as to be actively listening. In addition, the teacher can also search for some interesting English material, for example, broadcast films about poets and writers so that students could not only understand the life experience of poets and writers, but also feel the influence of English and Chinese in the films, and strengthen students' ability to communicate with each other in daily English. In the new period, in order to adapt to the trend of modernization, teachers must broaden students' knowledge, open their horizons, and improve students' interest in English courses through diversified teaching methods, so that they can be willing to learn English and enjoy English learning. After class, teachers can encourage students to go to the library to read more English books or listen to English songs through the Internet, so as to cultivate students' awareness of the English language and strengthen students' awareness of the English language through extensive reading.

3.4.2 carry out reverse classroom teaching to improve students' learning efficiency

Flip classroom is also called reverse classroom ${ }^{[7]}$, which refers to a teaching mode in which teachers make videos related to classroom teaching content in advance, students watch and learn independently at home or after class, and communicate face to face in class.
This teaching model can make students gradually become the protagonists of learning, and students communicate with teachers in the classroom, which is helpful to improve students' inquiry ability. therefore, college English teaching can also adopt the mode of reversal classroom to carry out teaching. Because college students allocate more time freely, the use of this method can also make English learning break through the limitations of time and space, so as to raise the point that this method can also break through the limitations of time and space in English learning.

\subsection{Establishment of perfect English examination system and evaluation system}

From the current situation of English education in China, there are still problems of imperfect English examination system and evaluation system in the process of English education in China, which directly affect the innovation of English education system ${ }^{[8]}$. To this end, the examination system as well as the evaluation system should be improved and innovated accordingly, mainly including the following two points: first, the proportion of listening and speaking ability test should be increased in the examination; second, the evaluation of the students' daily study should be strengthened, the evaluation should not only aim at the students' examination results, but also be carried out in the daily study performance, and the comprehensive evaluation of the students' classroom performance and the completion of homework after class, so as to Evaluate reasonably and scientifically the English comprehensive ability and the English learning ability of each student.

\section{6 strengthen the construction of English teachers}

With the development of economy and science and technology in our country, people are fully aware of the importance of English in the work and communication. On the basis of this, the number of English-speaking English majors has increased significantly in recent years, but the number of highly specialized English teachers is very limited. On the one hand, it has added to the difficulty of the existing excellent teacher teaching, and on the other hand it is not conducive to the development of our English education. Therefore, it is necessary to strengthen the construction of the English teaching staff. First, the school should increase the investment of the teacher's training, actively introduce the outstanding teachers' talents, and improve the teacher's salary treatment, so as 
to strengthen teacher's teaching enthusiasm, learning opportunities and platforms, constantly improve teachers' professional knowledge and ability; again, strengthen the assessment of teachers, so as to enhance teachers'sense of responsibility; finally, promote the communication between teachers, so as to facilitate teachers to learn and supervise each other, improve the overall level of teachers and build a high standard of teachers.

\section{Conclusion}

To sum up, in the new period, the society has put forward higher requirements for English talents, and English teaching has been paid more attention to in college education. However, in order to make college English education better adapt to the development trend of modern society, we must innovate from many aspects, such as teaching ideas, teaching methods and so on, so as to stimulate students' interest in learning English and improve their enthusiasm for learning. Only by adopting the teaching mode suitable for the development needs of students, enriching the teaching content and improving the diversity of English teaching, can we effectively improve the teaching quality and train better English talents for our country.

\section{references}

[1] Dandan. On the Innovation of College English Teaching
Method[J]. Overseas English,2018 (13):93-95.

[2] Jiang Lu. The innovative development of English education in colleges and universities under the background of new media [J]. Farm staff Officer, 2018 (24): 179.

[3] $\mathrm{Gu}$ Ruwen. A study on the Reform of College Foreign language Curriculum in China from the Perspective of General Education [D]. Nanjing University, 2013.

[4] Wu Wencong. A practical study on the Reform of English Education in Colleges and Universities under the Development of Social professionalization [J]. Think tank era, 2018 (27): 204206.

[5] Zhao Jingling, Li Xueqin. A study on the improvement of College English Teachers' Teaching ability under the background of Informatization [J]. Journal of Jiangxi Electric Power Vocational and Technical College, 2018, 31 (06):99.

[6] Chen Shaomin. On the Innovation and Development of English Education in Colleges and Universities in the New period [J]. Journal of Heilongjiang Institute of Education, 2015, 34 (08): 134.

[7] Zhang Qi. The Innovation and Development of College English Education in the New Period [J]. Contemporary Education Practice and Research,2015 (08): 174.

[8] Gao Yunfeng. On the Innovation and Development of English Education in Colleges and Universities in the New period [J]. Journal of Jilin Institute of Education (first ten days), 2015, 31 (03): 61 . 